Биологийн идэвхт нүүрсусаар баяжуулсан махан хүнс гарган авах

\title{
хими-технологийн судалгаа
}

\author{
Х.Бадамцэцэг ${ }^{1,2}$, Б.Мөнхжаргал ${ }^{1 *}$ \\ ${ }^{1}$ МУИС, Шинжслэх ухааны сургууль, Байгалийн ухааны сургууль, Улаанбаатар 14201, Монгол улс \\ ${ }^{2}$ Мах маркет ХХК, дотоод хяналтын лаборатори \\ *E-mail: monkhjargal@num.edu.mn
}

\begin{abstract}
\begin{tabular}{ll}
\hline Хүлээн авсан: 20.10 .2018 & Хяналтанд: 25.10.2018 Хэвлэлтэнд авсан: 03.11 .2018
\end{tabular}
Хураангуй: Пивоны шаар нь шар айрагны үйлдвэрийн гол дайвар бүтээгдэхүүн юм. Пивоны шаар нь арабиноксиланаар баялаг бөгөөд шүлтийн хандлалтаар гарган авч бүтээгдэүүнд нэмж туршилтын үр дүнг харьцуулан гаргасан. Зайдасны 4 дээж бэлдсэн. Хяналт (пивоны шаар/арабиноксилан 0\%, гахайн өөх 15\%), Д1 (пивоны шаар/арабиноксилан 5\%, гахайн өөх $10 \%$ нэмсэн), Д2 (пивоны шаар/арабиноксилан 10\%, гахайн өөх 5\%), Д3 (пивоны шаар/арабиноксилан 15\%, гахайн өөх $0 \%$ ). Зайдсанд гахайн өөхийг багасгаж шаараар орлуулснаар тослогийн агууламж, илчлэг чанар буурсан.
\end{abstract}

Түлхүур үге: пивоны шаар, арабиноксилан, тослогийн агууламж

\section{ОРШИЛ}

Шар айраг нь хэрэглээгээрээ ус, цайны дараа ордог бөгөөд манай орны хүн амын өсөлт, техник технологи хөгжихийн хирээр хүнсний үйлдвэрлэл тэр дундаа шар айрагны үйлдвэрлэл өргөжин хөгжиж, түүнийгээ дагаад үйлдвэрээс гарах хаягдал бүтээгдэхүүнүүд болох шаар, дрожжи, зөрөг цэцэг нэмэгдэж байна. Эдгээр дайвар бүтээгдэхүүнийг дахин боловсруулж хаягдалгүй эко үйлдвэрлэл явуулах нь шар айрагны үйлдвэрүүдийн хувьд тулгамдсан асуудлуудын нэг байсаар байна. Дайвар хаягдлын дунд шаар нь дийлэнх хувийг эзлэх ба сэргээгддэг хямд түүхий эд юм[1]. Шааранд 20\%-иас илүY уураг, 21.8-40.2\% арабиноксилан, 0.7-2\% фенолт нэгдэл, 5.3-22\% лигнин, 3-10\% липид, 12$21 \%$ целлюлоз агуулагддаг болохыг судлаачид тогтоосон байдаг. Арабиноксилан нь антиоксидант, микробын болон үрэвслийн эсрэг идэвхтэй тул зүрх судасны өвчин, цусан дахь холестерол бууруулах үйлчлэлтэй $[1,2]$. Иймд шар айрагны үйлдвэрийн хаягдлыг дахин боловсруулж, хүнсэнд нэмэлтээр хэрэглэх асуудал чухал болж байгаа тул судлахад хүргэж байна.

\section{СУДАЛГААНЫ МАТЕРИАЛ, АРГА ЗУЙ}

Судалгааны материал: Пивоны шаарыг 2017.11 сард MCS TIGER компанийн пивоны үйлдвэрээс авч (чийг нь 77\%) агаарт дэлгэж хатаасан (чийг нь 8.6\%). Дараагийн туршилт хүртэл $+4^{0} \mathrm{C}-\mathrm{T}$ хадгалав. Судалгааны арга зүй: Химийн найрлага: Хаягдал шаарны уургийн хэмжээг Кьелдалийн аргаар тодорхойлсон ба 0.5г дээжийг 9мл концентрацитай хүхрийн хүчилд 1 мл хлорын хүчлэн катализатортойгоор уусган уургийн амин хүчлийн азотыг аммонийн сульфатад шилжүүлсэн. Кельдалийн нэрэх аппаратанд $40 \%$ натрийн гидроксидоор аммиак үүсгэн нэрж борын хүчлийн $2 \%$ уусмалд шингээн давсны хүчлийн уусмалаар титрлэж тодорхойлов. Чийгийн хэмжээг $105^{\circ} \mathrm{C}-\mathrm{T}$ хатаах шүүгээнд хатааж тодорхойлов ба эрдсийн нийт хэмжээг $550^{\circ} \mathrm{C}$-т шатаах зууханд шатааж үнслэгийн хэмжээгээр нь тодорхойлсон. Тослогийн хэмжээг Сокслетын аппаратад эфирээр нэрж тодорхойлов [3].

Шаарнаас арабиноксиланыг ялган авах: 100 г шаар болон 500 мл 3 М КОН-г 1:5 г/л харьцаатайгаар авч антиоксидантаар $20 \mathrm{mM} \mathrm{NaBH} 4$ хийж $45^{\circ} \mathrm{C}$-ийн инкубаторт 7 цаг хандалсан. Ханд болон хатуу үеийг центрифугдэн салгасан. Ханд дээр $1 \mathrm{~N} \mathrm{HCl-ийн}$

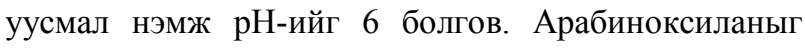
96\% (л/л) этанолоор тунадасжуулан ялгаж авав [4].

Бүтээгдэхүүнд нэмэх туриилтын явц: Хатааж тээрэмдсэн пивоны шаарнаас 5-15\%-ийг бусад орцуудын хамт зайдсанд нэмж туршилтуудыг хийсэн [5]. Пивоны шаар нь арабиноксиланаар баялаг бөгөөд шүлтийн хандлалтаар гарган авч бүтээгдэхүүнүүдэд нэмж туршилтын үр дүнг харьцуулан гаргав.

\section{ҮР ДУН, ХЭЛЭЛЩУУЛЭГ}

Пивоны шаарны химийн найрлага: Судалгаанд ашигласан MCS компанийн пивоны шаар нь 8.6\% чийгийн агуулгатай, 13.8\% уураг, $11.4 \%$ липид, 3.4\% эрдэс агуулж байна. Хэвлэлийн тоймтой 


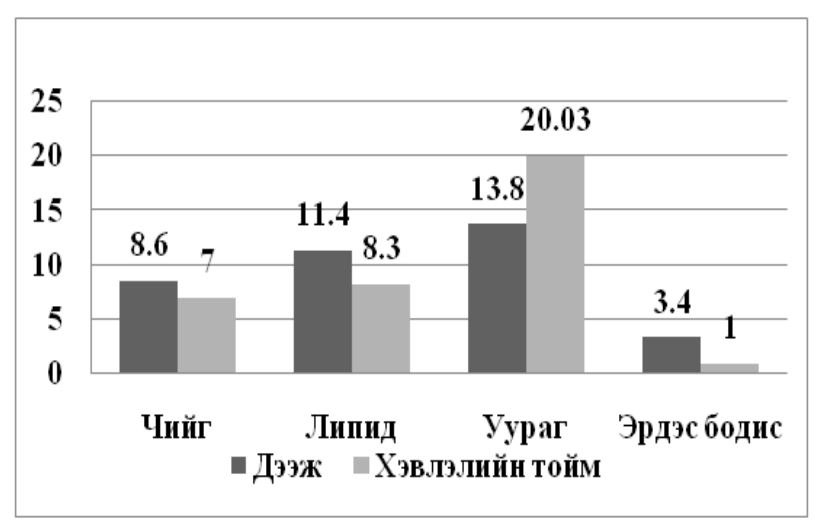

Зураг 1. Пивоны шаарны химийн найрлага

харьцуулахад үр дүн нь ойролцоо гарсан.

.MNS 0108:2007 стандартад заасан чийглэг, уураг, тослог, нүүрсус, үнслэг, илчлэг зэрэг үзүүлэлтүүдийг стандартын дагуу шинжиллээ [6-11]. Шинжилгээний үр дүнд нүүрсусны агууламж өсөж, тосны хэмжээ буурсан үзүүлэлттэй гарсан. (Зураг 2, 3)

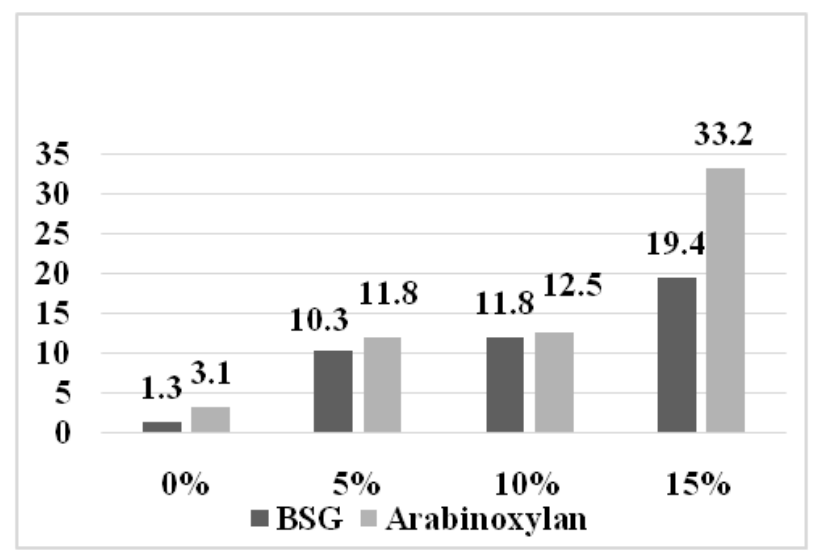

Зураг 2. НҮҮрсусны агууламжийн харьиуулалт, \% харьиуулалт, \%

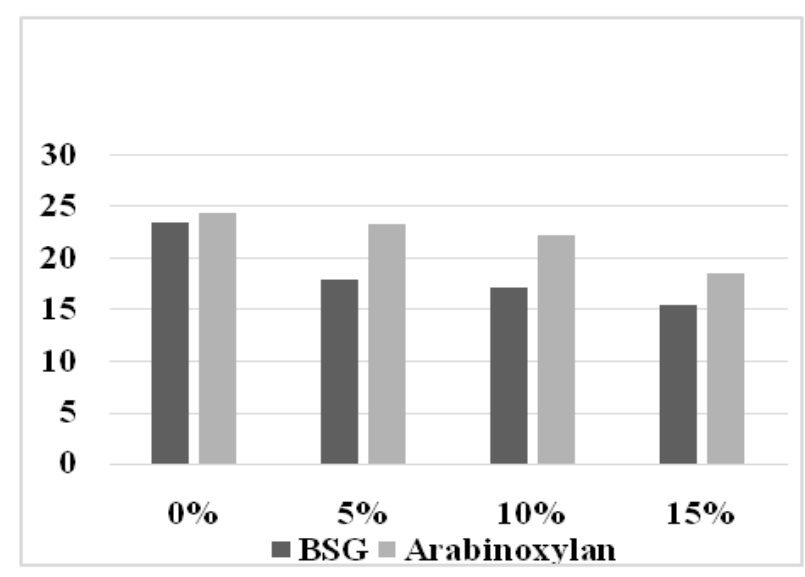

Зураг 3. Тосны агууламжийн харьиуулалт, \%

Мөн бүтээгдэхүүнд 1-10 гэсэн үнэлгээгээр амталгаа хийлгэхэд $5 \%$ агууламжтай бүтээгдэхүүн идэхэд тааламжтай боломжийн байна гэж дүгнэлээ. (Хүснэгт 1)
ХУснэгт 1. БүтээгдэхүҮнд амталгаа хийсэн Үнэлгээ

\begin{tabular}{ccccc}
\hline \multirow{2}{*}{ Боловсруулалт } & \multicolumn{4}{c}{ Үзүулэлт } \\
\cline { 2 - 5 } & $\begin{array}{c}\text { Гадаад } \\
\text { байда* }\end{array}$ & $\begin{array}{l}\text { Огтлолын } \\
\text { байдал* }\end{array}$ & Өнг* & $\begin{array}{c}\text { Амт, } \\
\text { үнэр* }\end{array}$ \\
\hline $0 \%$ & 9.7 & 8.5 & 8.7 & 8.6 \\
$5 \%$ & 9.5 & 8.2 & 8.2 & 8.1 \\
$10 \%$ & 9.6 & 8.1 & 8.3 & 8.3 \\
$15 \%$ & 9.6 & 7.9 & 8.1 & 7.7 \\
\hline
\end{tabular}

*Тайлбар:Гадаад байдал - БүрхүҮл хальс гэмтээгүй, гадаргуу нь иэвэр, толбогүй байна.

Огтлолын байдал: Таташ нь жигд холилдсон, нягт савлагдсан, бутарч унахааргүй байна.

\section{ДҮГНЭЛТ}

Шаарны найрлагын хувьд чийг 8.6\%, липид $11.4 \%$, уураг $13.8 \%$, эрдэс бодис $3.4 \%$ тус тус агуулагдаж байна. Шаар болон ялган авсан арабиноксиланыг зайдсанд 5-15\%-иар нэмж туршилт хийхэд зайдасны тослог 34\%-иар, арабиноксилан нэмсэн зайдасны тослог 24.5\%-иар багассан байна. Шинжилгээгээр бүтээгдэхүүн тус бүрд нүүрсусны агууламж өссөн Үзүүлэлт гарсан. Иймд нүүрсусаар баялаг функциональ хүнс гаргах боломжтойг харуулж байна. Мөн мэдрэхүйн үнэлгээгээр зайдсанд 5\%-иар нэмж хийхэд боломжтой гэж дүгнэлээ.

\section{АШИГЛАСАН НОМ, ХЭВЛЭЛ}

1. S.Ozturk, O.Ozboy, I.Cavidoglu, H.Koksel. Effects of brewer's spent grain on the quality and dietary fiber content of cookies, 108, 1, 2002.

2. V.Stojceska, P.Ainsworth, A.Plunkett, S.Ibanoglu, The recycling of brewer's processing by-product into ready to eat snacks using extrusion technology, Journal of cereal scence, 47, 2008, p. 469-479.

3. Д.Пүрэв, Н.Цэвэгсүрэн. Биоорганик химийн практикум. Урлах эрдэм, Улаанбаатар, 2001.

4. S.F.Reis, E.Coelho, N.A.Coimbra, N.Abu-Ghannam. Influence of grain particle sizes on the structure of arabinoxylans from brewer's spent grain, Journal of Elsevier, 2015.

5. M.Choi, Y.Choi, H.Kim, K.Hwang, D.Song, S.Lee, C.Kim. Effects of reflacing pork back fat with brewer's spent grain dietary fiber on quality characteristics of reduced-fat chicken sausages, Korean J.Food.Sci.An, 34, 2,2014, p. 158-165.

6. Монгол улсын стандарт. MNS 0108:2007 Төрөл бүрийн хиам. Техникийн ерөнхий шаардлага.

7. Монгол улсын стандарт. MNS 6477:2014 Max махан бүтээгдэхүүний чийглэг тодорхойлох арга.

8. Монгол улсын стандарт. MNS ISO 937:1984 Max 
махан бүтээгдэхүүн. Нийт азотын хэмжээг хэмжээг тодорхойлох арга.

9. Монгол улсын стандарт. MNS 1444:1984 Maх махан бүтээгдэхүүн. Чөлөөт тослогийн хэмжээг тодорхойлох арга.

10. Монгол улсын стандарт. MNS ISO 936:2003 Max махан бүтээгдэхүүн. Нийт үнслэгийг тодорхойлох арга.

11. Монгол улсын стандарт. MNS 5035:2001 Хоолны бодит илчлэгийг тодорхойлох шинжилгээний арга.

\title{
Chemistry technology research to produce meat enriched with biologically active carbohydrates
}

\author{
Kh.Badamtsetseg ${ }^{1,2}$, B.Munkhjargal ${ }^{1 *}$ \\ ${ }^{1}$ School of Arts and Sciences, National University of Mongolia, Ulaanbaatar 14201, Mongolia \\ 2 "Makh market" LLC, Ulaanbaatar 18132, Mongolia \\ *E-mail:monkhjargal@num.edu.mn
}

\begin{abstract}
Received: 20.10 .2018
Revised: 25.10 .2018

Accepted: 03.11.2018

Abstract: Brewery's spent grain is the main by-product of the brewing industry. The effects of replacing fat with arabinoxylan fraction of BSG for physicochemical, textural properties and sensory evaluations of reduced-fat sausages are evaluated. Control was prepared with $15 \%$ fat, and three reduced-fat sausages were formulated with 5,10 and $15 \%$ arabinoxylan fraction (T1 sausage with $5 \%$ of arabinoxylan fraction $+10 \%$ of fat, T2 sausage with $10 \%$ of arabinoxylan fraction $+5 \%$ of fat and T3 sausage with $15 \%$ of arabinoxylan fraction $+0 \%$ of fat). With increasing arabinoxylan fraction content in the sausage, the fat content and food calories are decreased in reduced-fat sausages.
\end{abstract}

Keywords: brewery's spent grain; arabinoxylan; reduced fat

(C) The Author(s). 2018 Open Access This article is distributed under the terms of the Creative Commons Attribution 4.0 International License (https://creativecommons.org/licenses/by/4.0/), which permits unrestricted use, distribution, and reproduction in any medium, provided you give appropriate credit to the original author(s) and the source, provide a link to the Creative Commons license, and indicate if changes were made.

DOI: https://doi.org/10.5564/bicct.v0i6.1108 